\title{
O que os fortes queriam? Uma análise de $O$ que é isso, companheiro? e Os carbonários
}

Ricardo Lísias ${ }^{1}$

Não surpreende que os últimos anos da ditadura militar brasileira tenham assistido ao enorme sucesso de dois livros voltados para as memórias de ex-guerrilheiros. O que é isso, companheiro?, de Fernando Gabeira, e Os carbonários, assinado por Alfredo Sirkis, confirmam a hipótese de que, depois de um período traumático, há uma grande necessidade de produção de memória. Os motivos são vários, e talvez o principal seja o de, em primeiro lugar, fazer um registro histórico com a intenção de reforçar a veracidade dos fatos traumáticos. Paul Ricoeur é claro: "Para falar sem rodeios, não temos nada melhor que a memória para significar que algo ocorreu" (Ricoeur, 2007, p. 40). A partir desse tipo de narrativa, os arquivos poderão ser constituídos e o trabalho do historiador, começar: "o testemunho constitui a estrutura fundamental de transição entre a memória e a história" (Ricoeur, 2007, p. 40).

A memória dos momentos traumáticos tem ainda diversas outras funções que vão da expiação do sofrimento à vontade de pedagogicamente registrar um fato doloroso para que ele não se repita. $\mathrm{O}$ testemunho também ajuda na reconstrução de ligações que acabaram rompidas de maneira abrupta. Através dele é possível retomar caminhos destruídos e ligações estilhaçadas. Beatriz Sarlo observa que entre nós isso foi muito comum: "Quando acabaram as ditaduras do sul da América Latina, lembrar foi uma atividade de restauração dos laços sociais e comunitários perdidos no exílio ou destruídos pela violência do estado" (Sarlo, 2007, p. 45).

O compartilhamento de experiências psicologicamente violentas, como se sabe, tem ação terapêutica também, já que transfere um dano de início individual para o coletivo, tornando-o, assim, um acontecimento social e, mais além, político:

O testemunho e a sua inscrição na cultura são recursos que permitem dar ao que aconteceu um lugar no Outro, sem o qual toda carga de angústia que acompanha o sobrevivente e seus

\footnotetext{
${ }^{1}$ Doutor em literatura brasileira e pós-doutorando na Universidade de São Paulo (USP), São Paulo, SP, Brasil. E-mail: rlisias@yahoo.com.br
} 
descendentes tenderiam a ficar à deriva, a se perpetuar em uma busca incessante de um lugar de inscrição (Macedo, 2015, p. 38).

Comentando um texto de Primo Levi, Marcio Seligmann-Silva esclarece a função de "trânsito" do texto memorialístico: "A narrativa teria, portanto, dentre os motivos que a tornaram elementar e absolutamente necessária, este desafio de estabelecer uma ponte com os 'outros', de conseguir resgatar o sobrevivente do sítio da outridade" (Seligmann-Silva, 2008, p. 66).

Além disso, muitos desses textos servem como gatilho para denúncias que depois serão utilizadas por possíveis iniciativas jurídicas; alguns procuram corrigir distorções históricas ou oferecer outras versões para um determinado fato e outros completam narrativas que acabaram difusas ou fragmentárias. Sem querer adiantar a discussão, depois da adaptação para o cinema de $O$ que é isso, companheiro?, alguns livros foram publicados complementado ou contradizendo trechos do filme e, lateralmente, do texto de Gabeira, que então voltou a ser discutido, 18 anos depois do lançamento. ${ }^{2}$

Os livros de Gabeira e Sirkis serviram, ainda, para recolocar o nome de seus autores em circulação. Protagonistas de momentos delicados, radicais e muito conhecidos da resistência à ditadura (o sequestro de diplomatas estrangeiros com o objetivo de obter a libertação de prisioneiros políticos), ambos pretendiam retornar à atividade política depois da anistia. O sucesso de seus relatos mostrava que tal intenção tinha respaldo: muita gente estava interessada no que eles tinham para dizer. ${ }^{3}$

O objetivo deste artigo é analisar como os narradores dos dois livros foram compostos, observando sua importância no interior das tramas, a intenção política dessa composição e suas consequências para a literatura e a sociedade brasileiras. A categoria do narrador, em suas variadas facetas, será o alvo específico das análises, porque ela parece ser uma grande preocupação dos autores contemporâneos, constituindo-se, portanto, como um reflexo do tipo de arte que produzem e, mais, agente

\footnotetext{
${ }^{2} \mathrm{O}$ livro Versões e ficções: o sequestro da história reuniu boa parte do debate publicado em torno da adaptação para o cinema do romance de Fernando Gabeira (Ridenti, 1997).

${ }^{3}$ Curiosamente, Fernando Gabeira e Alfredo Sirkis tiveram trajetórias parecidas: no retorno ao Brasil, ambos trouxeram na bagagem a pauta ecológica, participaram da criação do Partido Verde e concorreram à Presidência da República, sem a menor chance de sucesso, por essa sigla. Gabeira ocupou o cargo de deputado federal pelo Rio de Janeiro, enquanto Sirkis atuou mais regionalmente, no mesmo estado.
} 
de suas inquietações, investimentos e, sobretudo, ideologia. A inspiração é, em grande parte, retirada de Theodor W. Adorno:

Enquanto a existência e a função das obras de arte não levantavam problemas na sociedade e uma espécie de consenso reinava entre a sociedade segura de si e a posição das obras artísticas no seu seio, nunca pelo pensamento se inquiriu a significação estética: ela parecia um dado, algo evidente. As categorias só começam a ser objeto de reflexão filosófica quando, segundo Hegel, deixam de ser substanciais, não mais são imediatamente presentes e indiscutíveis (Adorno, 2003, p. 23).

A escolha da categoria do narrador, além de ser um agente ideológico, também se justifica pela sua capacidade de revelar aquele "Outro" que Ricoeur apontava como necessário para o tratamento do trauma. Ele é, portanto, central no texto memorialístico. Walter Benjamim nota como o narrador faz o trânsito do eu para o coletivo ao

recorrer ao acervo de toda uma vida (uma vida que não inclui apenas a própria experiência, mas em grande parte a experiência alheia. $\mathrm{O}$ narrador assimila à sua substância mais íntima aquilo que sabe por ouvir dizer). Seu dom é poder contar sua vida; sua dignidade é contá-la inteira. O narrador é o homem que poderia deixar a luz tênue de sua narração consumir completamente a mecha de sua vida. (Benjamin, 1994, p. 221)

Em capítulos curtos, com um texto ligeiro, O que é isso, companheiro? descreve a vertiginosa passagem de Fernando Gabeira pela luta armada. A intenção do texto memorialístico, declarada logo no início pelo autor, é entender o que teria acontecido com sua vida nos anos de militância:

Este portanto é o livro de um homem correndo da polícia, tentando compreender como é que se meteu, de repente, no meio da Irarrazabal, se há apenas cinco anos estava correndo da Ouvidor para a Rio Branco, num dos grupos que fariam mais uma demonstração contra a ditadura militar que tomara o poder em 64. Onde é mesmo que estávamos, quando tudo começou? (Gabeira, 1979a, p. 10).

A trama descreve um militante sem muita certeza da conveniência do que estava fazendo e, mais ainda, da ideologia do grupo que, também de um jeito meio confuso, ele aceitou integrar. Gabeira passa metade do livro preparando o auge: o sequestro do embaixador 
americano Charles Elbrick. O texto, porém, não diz exatamente como o narrador foi parar no pequenino grupo de pessoas que se refugiou na casa mais procurada do mundo no mês de setembro de 1969.4

O destino dos militantes se divide em duas partes: por um lado, a libertação do embaixador é heroica e com toques populares, terminando com os guerrilheiros no meio da torcida do Flamengo; por outro lado, a prisão aparece basicamente por um corte temporal e acaba anunciada ainda no meio do sequestro:

Quando voltei a Barão de Petrópolis, o carro de Helena estava estacionando. Corri e ainda consegui detê-la nas escadas. A turma de São Paulo não a conhecia e poderia ser que um deles estivesse de plantão, junto à porta da frente. Helena desconfiava de nossa participação no sequestro, mas não imaginava que o homem estava guardado ali. Saímos juntos, subindo a Barão de Petrópolis para tomar uma Coca em Laranjeiras. Fomos bastante fotografados naquela saída. Já na prisão, ao chegar no Cenimar, transferido de São Paulo, senti um certo clima de excitação. Quase toda a equipe que trabalhara na tocaia da Barão de Petrópolis estava por ali (Gabeira, 1979a, p. 123).

Dessa forma, não há suspense para o leitor: o narrador será preso, sabemos ainda antes do final da ação. Apesar de obter o resgate solicitado (a libertação de um grupo de presos políticos), somos logo informados de que as consequências do sequestro para os militantes serão duras.

Não é esse, porém, o único efeito do anúncio da prisão por um corte abrupto. $\mathrm{O}$ artifício acaba fazendo com que admiremos ainda mais a coragem daquelas pessoas que acabariam presas para libertar companheiros de luta. $\mathrm{O}$ medo que certamente abateria os guerrilheiros no intervalo entre o fim do sequestro e a prisão acaba aqui sendo retirado da trama, o que os torna figuras ainda mais heroicas. Estamos

\footnotetext{
${ }^{4}$ Durante o lançamento do filme $O$ que é isso, companheiro?, alguns militantes contestaram o lugar de importância de Fernando Gabeira no organograma das organizações de resistência, inclusive colocando sua inexperiência como empecilho para uma visão geral dos acontecimentos. Paulo Moreira Leite é claríssimo: "Gabeira entrou e saiu da operação como um militante raso do MR-8, ou pouco mais do que isso. Já residia na casa onde o embaixador foi abrigado - ali deveria cuidar da imprensa da organização - e por essa razão ficou no local. Na hora dos trabalhos finais de limpeza, Gabeira ficou encarregado de recolher um paletó que pertencia a um graduado participante do sequestro. Descuidou da tarefa, os militares descobriram a peça de roupa, localizaram o alfaiate e acabaram fazendo uma prisão importante" (Leite, 1997, p. 55).
} 
diante de pessoas corajosas. Como veremos adiante, esse recurso será fundamental para o efeito ideológico que o autor pretende alcançar.

A tortura que o narrador sofreu aparece apenas insinuada, por razões "éticas": "Falo da tortura como um artista, pois não tenho o direito de falar dela como um grande torturado" (Gabeira, 1979a, p. 155). A declaração é estranha e as aspas na palavra ética não são retóricas: Gabeira entrou para a vida pública no Brasil e ficou de fato famoso ainda no exílio por meio de uma longa entrevista publicada no Pasquim, cujo centro era justamente a tortura (Gabeira, 1979b). Já naquele momento, fazia ressalvas à sua possibilidade de se expressar como "vítima da tortura", mas ao mesmo tempo refletia sobre ela. O efeito no leitor é o de um narrador que busca uma espécie de lucidez integral, jamais esmaecida por um possível sofrimento físico. A memória seria, inclusive, a forma ideal para a conquista dessa confiabilidade política: "Vivemos uma época de forte subjetividade e, nesse sentido, as prerrogativas do testemunho se apoiam na visibilidade que o 'pessoal' adquiriu como lugar não simplesmente de intimidade, mas de manifestação pública" (Sarlo, 2007, p. 20).

O final de $O$ que é isso, companheiro? é melancólico e emotivo. Gabeira sai do Brasil, livre, aliás, pelo mesmo procedimento que adotara antes: seu nome estava na lista de prisioneiros que deveriam ser libertados se a ditadura quisesse resguardar a vida do embaixador alemão, sequestrado, por sua vez, por outro grupo de guerrilheiros.

O cárcere do diplomata da Alemanha é narrado justamente em Os carbonários, de Alfredo Sirkis, publicado alguns meses depois de O que é isso companheiro. Os volumes acabaram, portanto, tendo um oportuno aspecto complementar. Redigidas também em tom ligeiro e com algum sabor de aventura, as memórias de Sirkis começam no final da adolescência do autor, o que traz para suas ações iniciais certo ar de imaturidade: depois de ter escapado por um triz de um tiroteio, o narrador faz questão de descrever uma cena de sexo que protagonizara em uma praia carioca... Armado desde muito jovem, transmite sua valentia através de um clichê de western:

Sentei-me. Tirei o revólver da cintura e abri o tambor. Deixei as balas choverem na cama. Depois, peguei e meti, uma a uma, de volta nos pequenos orifícios de aço. Rodei o tambor e fiquei seguindo com os olhos o fundo dos cartuchos, que giravam num gracioso círculo dourado (Sirkis, 2008, p. 181). 
Um pouco mais abrangente no tempo do que o livro de Gabeira, Os carbonários faz uma espécie de panorama da resistência armada à ditadura, começando ainda na organização dos grupos, passando pelo momento mais ativo, descrevendo acontecimentos importantes como, além do sequestro dos diplomatas, o famoso congresso de outubro de 1968 da União Nacional dos Estudantes (UNE), até chegar ao desmantelamento quase completo das organizações. O relacionamento pessoal com Carlos Lamarca é um dos orgulhos do narrador.

Os carbonários termina da mesma forma que o livro de Fernando Gabeira: no dia 5 de maio de 1971, Alfredo Sirkis vai para o exílio, saindo do Brasil, com medo, mas de cabeça erguida: no aeroporto do Galeão, ele mostra o passaporte original para embarcar em um voo de carreira, como qualquer um dos outros passageiros.

As semelhanças entre os dois livros são bem maiores que as diferenças. Alfredo Sirkis parece enxergar com mais clareza do que Fernando Gabeira sua entrada na luta armada. Talvez por conta disso sinta-se um pouco menos mal na presença das armas de fogo. Seu livro também descreve melhor a estrutura das organizações de resistência e, do mesmo jeito, mostra mais intimidade com os mecanismos da guerrilha urbana.

Em diferentes formas e intensidade, a violência é um dos pontos em comum dos livros, talvez o que mais chame a atenção, já que praticamente constitui os narradores ou, se não tanto, cerca-os o tempo inteiro. A supressão dos direitos civis elementares atinge Gabeira e Sirkis diretamente: o primeiro, jornalista em início de carreira, sofre com a censura imposta gradativamente aos meios de comunicação; o autor de Os carbonários, por sua vez, está entrando no movimento estudantil quando a repressão aos grupos jovens organizados se torna muito forte, o que, aliás, adianta sua entrada nos grupos armados.

A violência física direta é a mais significativa e está presente com força nos dois livros. Arriscando-se o tempo inteiro, os dois narradores estão sempre à beira da prisão - o que de fato acaba acontecendo com Gabeira. Aqui e ali, advertem para a incerteza que sentem com relação à possibilidade de, simplesmente, continuarem vivos:

Será que chegaríamos à idade de Toledo? Será que usaríamos nossa pistola nos suspensórios e íamos preparar arroz de carreteiro nos futuros sequestros? Antes do exílio, eu me perguntava muito o que é que eu seria no futuro (Gabeira, 1979a, p. 128). 
Queria conhecer o mundo, viajar por aí. Mas não vou. Breve, o apagar da vida, como de uma lâmpada. No meio de uma balaceira, ou pior, muito pior, numa sala de torturas, totalmente nas mãos deles. Ou na melhor das hipóteses, depois de tudo, passar uma vida preso, enjaulado, feito uma fera (Sirkis, 2008, p. 423).

O leitor sabe que, encarcerados, a chance desses narradores sofrerem tortura é elevada. Aliás, praticamente incontornável, como eles próprios advertem:

E se eu não aguentar o pau? E se eu abrir? Se eu provocar quedas, mortes? Nessas alturas do campeonato, não dá mais para mistificar. Não abriu nada quem morreu no pau. Ou alguns caras velhos, muito experientes, um ou outro herói, como Bacuri (Sirkis, 2008, p. 423).

Por ser um ato de violência extrema e definidor de relações desumanas, o anúncio da possibilidade de tortura aproxima o leitor dos narradores. Se já nos prendemos pelo ritmo vertiginoso da narrativa e o inconformismo pela situação do país, a ameaça de tortura nos deixa solidários com os narradores e por fim aderimos a eles. A violência quase indizível da tortura faz com que a empatia entre o leitor e o livro se torne obrigatória para que nós também não percamos a humanidade e, inclusive, possamos continuar lendo esses relatos.

O anúncio da prisão dos companheiros é constante. Na cadeia de organização dos grupos de resistência, os narradores estão muito próximos das mãos dos torturadores. A informação sobre as prisões chega cercada de intimidade, no caso de Fernando Gabeira, ou como um fracasso quase organizacional, para Sirkis. De um jeito ou de outro, o tom de derrota traz junto o medo da captura e posterior violência:

O primeiro de nós a cair foi Cláudio. Um pouco antes dele, caíra Baiano, o jardineiro. Os homens invadiram a casa da Barão de Petrópolis e recolheram o exemplar do JB recortado na página dos pequenos anúncios. Foram imediatamente à coleção do Jornal e reconstituíram o anúncio rasgado, com o endereço da pensão. Era fácil distinguir Baiano entre os outros, pois havia se mudado recentemente e, além do mais, havia voltado à casa para me procurar e foi fotografado nas escadas (Gabeira, 1979a, p. 129, grifo nosso).

Desde que tinha começado a operação, tínhamos perdido mais de dez companheiros no Rio Grande do Sul e um no Rio, no aparelho de Jacarepaguá. Agora, mais dois em São Paulo. Da VPR restava apenas a UC Juarez de Brito na Guanabara, um ou dois 
gatos pingados em São Paulo e a área de trabalho no nordeste, a misteriosa coqueluche da organização. Era hora de parar e fazer um balanço. Se as coisas continuassem nesse ritmo, em poucos meses, talvez semanas, a VPR acabaria (Sirkis, 2008, p. 387).

Por falar em relações íntimas, a violência que o Estado impõe aos cidadãos é origem das fraturas afetivas que esses narradores vivem. Pessoas muito próximas desaparecem ou são feridas por ordem do regime militar, o que os atinge com muita força. Os afetos acabam sempre fraturados por causa da repressão. Gabeira tenta transmitir isso, por exemplo, através de um trecho onírico e algo cafona:

Se quisessem podiam te soltar, amigo. São incríveis os militares que se passaram para o nosso lado. Bem organizados, com disciplina. Centralismo é com eles. Falou tá falado. São decididos em tudo. Se um deles quisesse transar Márcia, por exemplo, deixava um bilhete: Companheira: encontre comigo de fronte ao 115 da Fonte da Saudade, às quatro horas da tarde de terça. Papo pessoal. Senha: Qual o caminho mais perto para Copacabana? Resposta: No seu caso, tomava um táxi. Se ia? Claro amigo, claro que ia. Ao invés disso, fico cheirando o travesseiro onde ela dormiu, trocando os lençóis com todas as possíveis secreções humanas. Cheiro bom? Claro, amigo. Se não é do companheiro? E daí? Senhora eu vos amo tanto, que até pelo vosso marido eu sinto um certo quebranto (Gabeira, 1979a, p. 103).

O narrador de Sirkis, como sempre um pouco mais leve, tenta aplacar o sofrimento de sua mãe com uma conversa veloz de telefone:

Sorvi uma vitamina de abacate num boteco e liguei para minha mãe, de um telefone público. Ela quase desmaiou do outro lado do fio. Mas ficou aliviada ao ouvir minha voz. Fazia um mês que eu não dava notícias. A preocupação materna atravessou vários quarteirões pelo cabo da Telerj.

- Meu filho, onde você está?

- Estou perto mas não podemos nos ver. É só para dizer que estou bem. Tenho que voltar para São Paulo hoje mesmo, não se preocupe...

Falamos mais uns minutos e depois desliguei, cheio de culpa (Sirkis, 2008, p. 380).

Muitas vezes a tortura é uma espécie de absurdo pelo qual eles temem ter se passar. Porém, é importante deixar claro aqui que não há 
nos dois livros nenhum tipo de "visão de sacrifício" no que diz respeito à violência física. Os narradores enxergam tudo de forma política e não estão se arriscando, de maneira nenhuma, para se engrandecer. Nenhum dos dois enxerga absolutamente nada de bom na tortura. Quando reflete sobre ela, inclusive, Fernando Gabeira é enfático:

Nunca mais poderia pensar em ser brasileiro, sem levar em conta essa realidade. Depois da PE da Barão de Mesquita, todos nós, inocentes ou não, ficamos horrorizados com o Brasil e com o ser humano. Creio que começava a entender a tentativa de suicídio de Frei Tito de Alencar, na Operação Bandeirantes. Mas não estou autorizado a especular sobre a tentativa de suicídio de ninguém. Apenas digo: compreendi a possibilidade do suicídio (Gabeira, 1979a, p. 172).

O que também dá autenticidade a esses narradores e, ao mesmo tempo, fortalece seus testemunhos, por fim, é o fato de terem sobrevivido à violência que, em intensidade e formas diferentes, cercava-os e vitimou quase todos ao redor. Fernando Gabeira explica melhor e mais diretamente:

Os participantes da ação se dispersaram a partir da noite de domingo. Dois morreram: Toledo sob torturas em São Paulo; Jonas, o comandante militar da ação, massacrado a pontapés pela equipe do Capitão Albernaz, na operação Bandeirantes. Alguns foram presos e liberados, depois de cumprirem a pena; outros foram liberados, por sequestro, e vivem em lugares diferentes, no exílio. Alguns fugiram e, finalmente, um de nós enlouqueceu e perambula pelas ruas de Paris, de barba e cabelo grande. Sobrevivi. E pensei que talvez fosse interessante contar a história (Gabeira, 1979a, p. 130).

Tratando de um assunto também muito traumático, o bombardeio à cidade de Dresden durante a II Guerra Mundial, o escritor W. G. Sebald observa como muitas vítimas de violência acabam, por muitas razões, silenciando-se:

Contudo, por meio de fragmentos de recordação desse tipo, entendese talvez que é impossível sondar as profundezas da traumatização nos espíritos de quem escapou dos epicentros das catástrofes. $\mathrm{O}$ direito ao silêncio que essas pessoas em sua maioria se arrogam é tão inviolável quanto o dos sobreviventes de Hiroshima. A respeito desses sobreviventes, Kenzaburo Oe, em suas anotações feitas sobre a cidade em 1965, conta que muitos deles, vinte anos depois da 
explosão da bomba, ainda não conseguiam falar sobre o que acontecera naquele dia (Sebald, 2011, p. 81).

Nossos narradores, então, venceram inclusive a força que impele muitas vítimas de trauma ao silêncio. Mais do que simplesmente narrarem, ambos trazem ainda a habilidade de contar tudo de maneira literária. Fernando Gabeira chama a si mesmo de artista (no trecho citado sobre a tortura) e, um pouco menos pretensioso, Sirkis quer ser um bom contador de histórias, o que consegue com bastante sucesso, aliás. Os carbonários é lido de um fôlego só.

Esses dois narradores também são lúcidos e íntegros a ponto de refletir sobre as próprias ações e, ainda mais, apontarem diversos erros em suas trajetórias:

Marginal não dá voto, marginal não faz greve. A violência a que era submetido o preso comum não foi discutida em detalhe, não foi analisada minuciosamente. Não estaríamos reproduzindo em relação a eles aquele mesmo mal-estar, aquela mesma pressa de encerrar o assunto que era comum nas classes médias, quando se falava de tortura aos presos políticos? Tudo isso ia se revelando dolorosamente lógico. Era lógico que fizessem isso no Brasil, pois até a esquerda, até a oposição pareciam bastante insensíveis para esta dimensão da violência. As táticas e os programas são para as classes sociais. Os marginais eram desclassificados: fogo neles. Pois é: não é a polícia brasileira que é violenta. Nós somos violentos. Há uma parte nossa que espera lugar no museu de Horrores da humanidade (Gabeira, 1979a, p. 180).

A propósito, esse é um dos poucos momentos em que o narrador de Alfredo Sirkis é de fato duro e se expressa em tom indignado:

Recentemente um militante da ALN, preso, passara a colaborar com a OBAN e a fazer declarações para o regime na televisão. A suspeita de que isso se repetiria se instalara na mente paranoica daqueles companheiros. O processo de intenção foi sumário, dera pena de morte na rua, sem apelação. O estúpido crime criara certa comoção dentro da ALN. A maior parte dos militantes e mesmo dos quadros de direção sequer tinham sido consultados. Souberam pelos jornais.

- Foi uma cagada terrível, não tivemos nada com isso - garantiam consternados.

Notem bem, consideravam uma cagada, não um crime. Este era o nível médio de consciência que a esquerda tinha (Sirkis, 2008, p. 413). 
A autocrítica, a relativização da própria ideologia e a exposição dos defeitos e fraquezas de si mesmo e dos outros têm nos dois relatos uma dupla função. Em primeiro lugar, seguem o clichê de criar as chamadas "personagens redondas", figuras contraditórias e complexas, mais ou menos como qualquer pessoa real. Seguindo a leitura popularizada da literatura realista, essa é a maneira como o romance de viés mais popular constrói suas personagens até hoje: pessoas contraditórias e sem plenas certezas de suas convicções. Depois, esse tipo de recurso costuma gerar no leitor empatia e, dependendo da habilidade do autor, adesão a suas hipóteses políticas, atitudes e opções. Afinal de contas, são gente como a gente.

Em resumo, os narradores de Sirkis e Gabeira vão aos poucos ultrapassando todo tipo de dificuldade, mostrando serem complexos, contraditórios e ao mesmo tempo corajosos, desafiam o perigo e, ainda que sintam medo, continuam. Negam o lugar de heróis, mas sem dúvida enfrentam um inimigo muito mais forte e poderoso por convicções políticas. No final, ainda conseguem lucidez e ânimo, contra forças que poderiam impulsioná-los ao silêncio, para contar suas memórias com habilidade e certo tino literário.

No final, contas feitas, o fato é que $O$ que é isso companheiro? e Os carbonários, dois dos livros de maior sucesso do Brasil durante a transição para a democracia, constituem um narrador forte e robusto. Se a ditadura estava derrotada, na expressão de Élio Gaspari, alguns de seus combatentes retornavam ao Brasil com toda força e prontos para transmitir sua ideologia e, como vimos, inclusive pleitear cargos políticos. A pergunta decisiva, portanto, é direta: que ideologia a força desses dois narradores desejava transmitir?

$\mathrm{Na}$ teia de vozes que estavam se constituindo durante o fim da ditadura militar, as de Fernando Gabeira e Alfredo Sirkis aparecem, portanto, ocupando um lugar privilegiado e se expressando com força e muita habilidade de convencimento. Foram vozes premiadas, é preciso ressaltar: os dois livros receberam o Prêmio Jabuti em suas respectivas categorias no ano seguinte ao do lançamento. Vale lembrar agora que ambos retornam de um longo período de exílio na Europa. Se a distância forçada do país lhes causara sofrimento, também fez com que tivessem contato com o que alegadamente seriam as manifestações políticas mais modernas e esclarecidas. Depois de advertir que as novas formas de fazer política (os movimentos de defesa dos direitos das minorias) chegaram ao 
Brasil um pouco antes dele, Gabeira coloca-se como a personificação de uma vida mais desenvolvida: "minha maneira de viver era em si um estímulo para milhares de pessoas que queriam levantar a cabeça" (Gabeira, 1981, p. 165).

O trabalho de "renovação" obviamente exigia que antigas questões fossem deixadas para trás. Dessa forma, O que é isso companheiro? e Os carbonários oferecem também a função de acerto de contas ou, mais que isso, superação da resistência à ditadura. Escritos no final da década de 1970, os dois livros já se apresentam como o relato de uma experiência derrotada. É assim que Gabeira, na quarta página de seu livro, descreve o golpe militar e a luta de resistência:

Começávamos a engolir sapos e sequer imaginávamos que íamos continuar a engolir sapos durante 15 anos, nas mais variadas circunstâncias. [...] Mais tarde, nas noites de clandestinidade, ou mesmo nas conversas de cadeia, pude ir ligando coisas, compondo um quadro mais claro do que foi o golpe de 64. Para começar ia respondendo as perguntas mais elementares. Onde é que estavam os estudantes? [...] A mesma disposição heroica, as mesmas frases de efeito: resistir até o último homem ou então: daqui a pouco chega, as armas do dispositivo militar do Presidente. E as armas, Antonio? As armas que você traria pra nós, Antonio Duarte, da Associação dos Marinheiros? Quantas vezes não perguntei isso durante as partidas de xadrez no exílio (Gabeira, 1979a, p. 12).

Já Alfredo Sirkis sequer espera o início das memórias e se apresenta como derrotado no prefácio da primeira edição de seu livro: "Erros cometemos muitos e a validade do gesto moral não atenua a dimensão daquela derrota, que custou muitas vidas queridas e valiosas" (Sirkis, 2008, p. 35).

Ao aceitar a imagem da "guerra" ou, se não tanto, de um enfrentamento legítimo, esses dois narradores acabam declarando o governo militar como vitorioso de uma contenda que só a esse último interessava criar. Ao longo dos livros, a força desses narradores se intensifica, ficando a vitória que atribuem à ditadura bastante fortalecida. Não é exagero dizer que o tempo inteiro os dois livros, com o argumento de analisar as próprias fraquezas ou obedecer a algum tipo de impulso de integridade, como vimos, diminuem a importância dos grupos de resistência, chegando em alguns momentos até à zombaria:

- Como é, já entrou para o Partido Comunista? 
- Eu não, e seus garotos?

- Que garotos?

- Seus filhos.

- Que filhos? Não tenho filhos.

- Como, se você é o pai que virou a assembleia, o pai da nossa greve?

- Olha, o negócio é o seguinte: não sou pai de ninguém. Os pais que iam à assembleia ficaram doentes e o Partido acabou determinando que eu fosse fazer o papel de pai. Tinha cabelo branco, sabia falar. Agora já acabei com isso. Acho muito chato.

- O que é que você está tomando? Perguntei ainda meio surpreso com aquela história.

- Caipirinha. Tá boa. Pede uma também.

Foi nossa única referência ao Partido Comunista (Gabeira, 1979a, p. 26).

- Se vocês puxassem um fumo, veriam que essa revolução não vai dar certo. Em todo caso, respeito o caminho que escolheram (Gabeira, 1979a, p. 73).

- Foi uma lição para Rockfeller. Dois vidros quebrados na Sears e um no Lar Brasileiro (Gabeira, 1979a, p. 82).

Eu queria dizer tanta coisa, Elias. Talvez dar um informe. O informe você sabe, começa com a situação internacional: o capitalismo está numa crise agonizante e o socialismo avança em todo o mundo. Ou então uma frase geral: a realidade mais uma vez comprovou o acerto de nossas análises (Gabeira, 1979a, p. 102).

Depois veio a proibição dos murais da turma, onde colávamos recortes com artigos de jornal. Finalmente o mural afixado no pátio, feito com artigos dos alunos, caricaturas, fotos etc. Neste dia cometi meu primeiro ato terrorista. Passando pela janela aberta do gabinete da diretoria, esguichei toda a tinta da minha caneta Parker na sua cortina amarela (Sirkis, 2008, p. 59).

A formatura ia transcorrendo normalmente. Eu presidia a mesa, representando o grêmio livre. Falaram os oradores da turma. A plateia de alunos e pais, uns duzentos no máximo, escutava atenta e batia palmas. Novamente tínhamos o Che Guevara de paraninfo (Sirkis, 2008, p. 131). 
Em desespero de causa, Alex, com seu GTA, assaltou a telefônica de Ipanema, convencido de que as chamadas deviam dar uma nota. Rendeu todo mundo, limpou a caixa. Rendeu uns tostões e centenas de fichas telefônicas.

- Tive tanta vergonha que escondi a metralhadora atrás do casaco, para ninguém ver - confessou-me depois (Sirkis, 2008, p. 298).

Uma vez me acusou de pequeno-burguês por ter fritado um ovo na manteiga.

- Gastar manteiga à toa. É mesmo coisa de pequeno-burguês! (Sirkis, 2008, p. 354).

Como se sabe, a principal questão política durante o final da ditadura militar, além das eleições diretas, era a anistia judicial aos crimes cometidos por agentes políticos do Estado. Uma das principais exigências para devolver o poder às mãos da sociedade civil era a de que não houvesse punição pelos crimes das décadas anteriores. O Estado exigia que os agentes que a seu serviço cometeram crimes permanecessem impunes. $\mathrm{O}$ pretexto era o de que o país vivera uma guerra, com baixas dos dois lados. ${ }^{5}$

Não é o objetivo aqui discutir essa tese, que foi esmiuçada e implodida desde que surgiu, apesar de ter saído vencedora no campo político. Cabe apontar que os dois principais livros de memórias surgidos logo no final da ditadura militar utilizaram vários procedimentos literários para aderir ao desejo da ditadura e com isso colaboraram para que nenhum abuso cometido pelo Estado fosse levado à justiça.

Narradores fortes constituindo uma democracia fraca.

A chegada de Fernando Gabeira e Alfredo Sirkis na Europa corresponde à ascensão de novas formas de pensar a política depois dos movimentos de maio de 1968, que se consolidavam justamente na década de 1970. São questões que transformaram inclusive o eixo dos movimentos sociais:

O movimento ecológico, um tipo de política pós-moderna, está dividido em desterritorialização e regionalismo. Alguns argumentam que a comunidade é o melhor espaço para a vida econômica, política e cultural, e que as relações sociais

\footnotetext{
5 A hipótese da "guerra" entre governo e resistentes ficou conhecida como "Teoria dos dois demônios" e foi defendida não apenas no Brasil. Para uma apresentação assinada por dois especialistas, ver Meyer e Silva Filho (2014).
} 
comunitárias deveriam ser horizontais, em oposição à configuração vertical (hierárquica) de poder inerente às versões estáticas da ordem social (Aronowitz, 1991, p. 159).

Mais do que observar a pertinência da transformação, seu alcance, consequências e polêmicas, o que importa, no caso particular dessa análise, é notar que os dois autores trouxeram na bagagem, ao voltar do exílio, um tipo de pensamento ideológico ainda novo para o Brasil, mas que, obviamente, tinha ele próprio atravessado diversas etapas em seus espaços de desenvolvimento.

Antes militantes de organizações com graus diferentes de compreensão do pensamento de esquerda tradicional, Gabeira e Sirkis irão, no início dos anos 1980, voltar à vida política representando o chamado movimento ecológico. A propósito, um dos líderes de maio de 68, Daniel Cohn Bendit, é apresentado entre nós por um livro de diálogos com Fernando Gabeira, sintomaticamente intitulado Nós que amávamos tanto a revolução (Gabeira, 1985), publicado com alarde em 1985, ainda na onda do sucesso de O que é isso, companheiro?

Portadora de uma questão ideológica que supostamente seria mais arejada, a luta ecológica, justa e razoável, acompanha outras fragmentações do cotidiano da política, os assim chamados direitos de grupos marginalizados. Tomam força os movimentos em defesa das mulheres, dos homossexuais e da população negra, entre outros.

Atravessando um histórico de violência, obviamente, os grupos citados precisam de todo tipo de representatividade nas instâncias democráticas. Mas, para alcançá-la - e isso não ocorreu efetivamente até hoje -, parte grande dos atores políticos brasileiros que atuavam no final da ditadura militar aceitaram o discurso do governo de que era preciso "virar aquela página da história" sem contestações judiciais e, com uma ansiedade certamente prejudicial para a maturidade das instituições brasileiras, saltaram alguns passos, deixando a vida democrática entre nós bastante frouxa. Não é possível esperar que a justiça vá garantir progresso na questão ambiental, proteção aos grupos homossexuais, leis antiracismo amplas e efetivas e ações contra o feminicídio quando há torturados identificados e muitas vezes confessos que não são interpelados pelo sistema judiciário.

Meios que antes resistiam à ditadura acabaram relativizando sua luta em prol de uma "pacificação" muito veloz. A anistia que livrou torturadores da justiça, o que obviamente enfraquece as instituições 
jurídicas, não é a única consequência disso. Ao tirar a importância histórica da própria luta, esses grupos acabaram deixando como herança para os movimentos sociais posteriores um vocabulário enviesado e interessado em aproximá-los da criminalidade. Trabalhadores sem-terra e sem-teto são frequentemente chamados de "terroristas", talvez porque a palavra não tenha sido esclarecida: antes, "terroristas" eram os grupos de resistência à ditadura. Infelizmente, no Brasil, não seguimos a ressalva de Fredric Jameson: "o que é muitas vezes chamado de 'terrorismo' deve ser objeto de uma complexa análise propriamente dialética” (Jameson, 1992, p. 118).

Há outras consequências da operação levada a cabo por esse discurso: ao ridicularizar e tirar a legitimidade da resistência à ditadura, livros como $O$ que é isso companheiro? e Os carbonários caminham em direção a um discurso que procura estar a favor do pensamento oficial. Pode estar aqui o germe de uma literatura sempre a favor da norma, estranha à contestação e tentando agradar ao maior número possível de leitores. Seus autores, além de tudo, também queriam votos...

\section{Referências}

ADORNO, Theodor W. (2003). Experiência e criação artística. Tradução de Artur Morão. Lisboa: Edições 70.

ARONOWITZ, Stanley (1991). Pós-modernismo e política. Tradução de Cristina Cavalcanti. In: HOLANDA, Heloísa Buarque de (Org.). Pós-modernismo e política. Rio de Janeiro: Rocco, p. 151-175.

BENJAMIM, Walther (1994). O narrador: considerações sobre a obra de Nikolai Leskov. In: BENJAMIM, Walther. Magia e técnica, arte e política. Tradução de Sergio Paulo Rouanet. São Paulo: Brasiliense, p. 197-221.

GABEIRA, Fernando (1979a). O que é isso, companheiro? Rio de Janeiro: Codecri.

GABEIRA, Fernando (1979b). Carta sobre a anistia. Rio de Janeiro: Codecri.

GABEIRA, Fernando (1981). Entradas e bandeiras. Rio de Janeiro: Codecri.

GABEIRA, Fernando; Daniel Cohn Bendit (1985). Nós que amávamos tanto a revolução. Rio de Janeiro: Rocco. 
JAMESON, Fredric (1992). Periodizando os anos 60. Tradução de Cézar Brittes e Maria Luiza Borges. In: HOLANDA, Heloísa Buarque de (Org.). Pós-modernismo e política. Rio de Janeiro: Rocco, p. 81-126.

LEITE, Paulo Moreira (1997). O que foi aquilo, companheiro? In: REIS FILHO, Daniel Aarão et al. Versões e ficções: o sequestro da história. São Paulo: Fundação Perseu Abramo, p. 51-60.

MACEDO, Lucíola Freitas de (2015). O testemunho, entre o poético e o político. Cult, São Paulo, n. 199, mar.

MEYER, Emilio Peluso Neder; SILVA FILHO, José Carlos Moreira da (2014). O engodo de uma "teoria dos dois demônios" à brasileira. Consultor Jurídico, São Paulo, 28 dez. Disponível em: <http://www.conjur.com.br/2014-dez28/engodo-teoria-dois-demonios-brasileira>. Acesso em: 22 jul. 2015.

RICOEUR, Paul (2007). A memória, a história, o esquecimento. Tradução Alain François et al. Campinas: Editora da Unicamp.

RIDENTI, Marcelo et al. (1997). Versões e ficções: o sequestro da história. São Paulo: Fundação Perseu Abramo.

SARLO, Beatriz (2007). Tempo passado: cultura da memória e guinada subjetiva. Tradução de Rosa Freire d'Aguiar. São Paulo: Companhia das Letras; Belo Horizonte: Editora UFMG.

SEBALD, Winfried Georg (2011). Guerra aérea e literatura. Tradução de Carlos Abbenseth e Frederico Figueiredo. São Paulo: Companhia das Letras.

SELIGMANN-SILVA, Márcio (2008). Narrar o trauma: a questão dos testemunhos de catástrofes históricas. Psicologia clínica, Rio de Janeiro, v. 20, n. 1, p. 65-82.

SIRKIS, Alfredo (2008). Os Carbonários. Rio de Janeiro: Bestbolso.

Recebido em setembro de 2015.

Aprovado em fevereiro de 2016.

\section{resumo/abstract/resumen}

\section{O que os fortes queriam? Uma análise de $O$ que é isso, companheiro? e Os carbonários}

Ricardo Lísias

O artigo analisa a constituição do narrador de dois livros de memória publicados no final da última ditadura militar brasileira - O que é isso, companheiro?, de Fernando Gabeira, e Os carbonários, de Alfredo Sirkis -, 
procurando observar a maneira com que ambos transmitiam a ideologia de pacificação que marcou a fase de transição. Os dois livros fizeram um enorme sucesso assim que foram lançados, seus autores cumpriram trajetórias políticas muito parecidas e seus textos podem ser, assim, considerados paradigmáticos de um discurso que aos poucos tomou conta do Brasil e teve diversas consequências para a reconstrução das instituições nacionais.

Palavras-chave: ditadura militar brasileira, redemocratização, texto memorialístico, narrador, Fernando Gabeira, Alfredo Sirkis.

\section{What did the strong ones want? An analysis of $O$ que é isso, companheiro? e Os carbonários}

Ricardo Lísias

The article analyzes the constitution of the narrator in two memoires published at the end of the last Brazilian military dictatorship - Fernando Gabeira's O que é isso, companheiro?, and Os carbonários, by Alfredo Sirkis - trying to observe the way in which both conveyed the ideology of peacemaking that marked the transitional period. Both books enjoyed considerable success upon their release, their authors followed very similar political trajectories, and the texts can thus be considered paradigmatic of a discourse that gradually took over Brazil and had various consequences for the reconstruction of national institutions.

Keywords: Brazilian military dictatorship, redemocratization, memorialistic text, narrator, Fernando Gabeira, Alfredo Sirkis.

\section{¿Qué querían los fuertes? Una análise de $O$ que é isso, companheiro? e Os carbonários}

\section{Ricardo Lísias}

El artículo analiza la constitución del narrador de dos libros de memorias publicados hacia fines de la última dictadura militar brasileña -O que é isso, companheiro?, de Fernado Gabeira, y Os carbonários, de Alfredo Sirkis -, buscando observar la manera en la que ambos transmitían la ideología de pacificación que marcó el período de transición. Los dos libros tuvieron un gran éxito apenas lanzados y sus autores compartieron una trayectoria política muy similar. Podríamos, entonces, considerar estos textos como paradigmáticos de un discurso que poco a poco fue dominante en el Brasil y que tuvo diversas consecuencias para la reconstrucción de las instituciones nacionales.

Palabras clave: dictadura militar brasileña, redemocratización, texto memorialístico, narrador, Fernando Gabeira, Alfredo Sirkis. 